\title{
Pim-I kinase phosphorylates RUNX family transcription factors and enhances their activity
}

\author{
Teija LT Aho ${ }^{1,2}$, Jouko Sandholm ${ }^{1}$, Katriina J Peltola ${ }^{1,2}$, Yoshiaki Ito ${ }^{3}$ and \\ Päivi J Koskinen*1
}

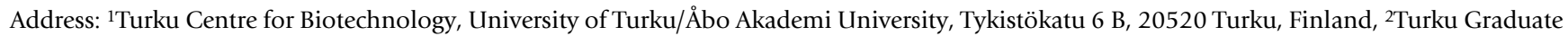
School of Biomedical Sciences, University of Turku, Kiinamyllynkatu 13, 20520 Turku, Finland and 3Institute of Molecular and Cell Biology, 61 Biopolis Drive, Singapore 138673, Singapore

Email: Teija LT Aho - teija.aho@utu.fi; Jouko Sandholm - jouko.sandholm@btk.fi; Katriina J Peltola - katriina.peltola@iki.fi; Yoshiaki Ito - itoy@imcb.a-star.edu.sg; Päivi J Koskinen* - paivi.koskinen@btk.fi

* Corresponding author

Published: 09 May 2006

BMC Cell Biology 2006, 7:21 doi:10.||86/|47|-2|2|-7-2|
Received: 16 February 2006

Accepted: 09 May 2006

This article is available from: http://www.biomedcentral.com/I47I-2/2I/7/2I

(C) 2006 Aho et al; licensee BioMed Central Ltd.

This is an Open Access article distributed under the terms of the Creative Commons Attribution License (http://creativecommons.org/licenses/by/2.0), which permits unrestricted use, distribution, and reproduction in any medium, provided the original work is properly cited.

\begin{abstract}
Background: The pim family genes encode oncogenic serine/threonine kinases which in hematopoietic cells have been implicated in cytokine-dependent signaling as well as in lymphomagenesis, especially in cooperation with other oncogenes such as myc, bcl-2 or Runx family genes. The Runx genes encode $\alpha$-subunits of heterodimeric transcription factors which regulate cell proliferation and differentiation in various tissues during development and which can become leukemogenic upon aberrant expression.
\end{abstract}

Results: Here we have identified novel protein-protein interactions between the Pim-I kinase and the RUNX family transcription factors. Using the yeast two-hybrid system, we were able to show that the C-terminal part of human RUNX3 associates with Pim-I. This result was confirmed in cell culture, where full-length murine RunxI and Runx3 both coprecipitated and colocalized with PimI. Furthermore, catalytically active Pim-I kinase was able to phosphorylate RunxI and Runx3 proteins and enhance the transactivation activity of RunxI in a dose-dependent fashion.

Conclusion: Altogether, our results suggest that mammalian RUNX family transcription factors are novel binding partners and substrates for the Pim-I kinase, which may be able to regulate their activities during normal hematopoiesis as well as in leukemogenesis.

\section{Background}

The pim-1 proto-oncogene was first identified as a common proviral insertion site associated with murine leukemiavirus-induced lymphomagenesis, and its oncogenic activity was verified with transgenic mice overexpressing pim-1 in the lymphoid compartment [1]. These mice show a low incidence of spontaneous T-cell lymphomas, the development of which can be accelerated by activation of cooperating oncogenes, such as $m y c$ family genes, $b c l-2$ or
Runx2 [1-3]. Two additional, functionally redundant pim family members have been identified with partially overlapping expression patterns. The murine pim-1 gene encodes 44 and $34 \mathrm{kD}$ isoforms of a serine/threonine-specific kinase [4], whose expression in hematopoietic cells can be induced by a variety of cytokines, such as interleukins 2, 3, 6 and interferon- $\alpha$ [5-7]. We and others have shown that Pim-1 is involved in cytokine-dependent signaling via its ability to regulate activities of the NFATc [8] 
and c-Myb [9] transcription factors, the Epstein-Barr virus nuclear antigen-2 [10] and the SOCS family suppressors of cytokine signaling $[11,12]$. Pim kinases also enhance hematopoietic cell survival and participate in regulation of the cell cycle [13].

RUNX family proteins (also known as AML, PEBP2 $\alpha$ or $\mathrm{CBF} \alpha$ ) [14] are DNA-binding $\alpha$-subunits of heterodimeric transcription factors that are essential for both cell proliferation and differentiation during development [15]. Homozygous disruption of murine Runx2 results in complete lack of bone formation, Runx1 knockout mice are embryonally lethal due to failure of definitive hematopoiesis, and Runx3-deficient mice display abnormal development of gastric epithelium and dorsal root ganglion as well as defects in thymopoiesis. In addition, strict spatiotemporal expression of all Runx family genes is critical for normal hematopoiesis [16]. The RUNX proteins contain an evolutionary conserved region, the Runt domain, which has been named after their structural homologue in Drosophila [17]. This region is required for DNA-binding as well as for dimerization with the $\beta$-subunit. While three mammalian genes encode $\alpha$-subunits: RUNX1 (PEBP2 $\alpha B$ ), RUNX2 (PEBP2 $\alpha A$ ) and RUNX3 (PEBP2 $\alpha \mathrm{C})$, only one gene has been identified for the $\beta$-subunit (PEBP2 $\beta / \mathrm{CBF} \beta$ ). The $\beta$-subunit can enhance DNA-binding by the Runt domain but does not contact DNA itself $[15,18]$. There is less sequence similarity between RUNX family members outside the Runt domain, except for the highly conserved five amino acid C-terminus (VWRPY) known to bind transcriptional repressors, but the C-terminal regions are rich in proline, threonine and serine (PTS) and contain domains involved in transcriptional activation or inhibition [19]. RUNX activity has recently been shown to be regulated by several extracellular signaling pathways resulting in post-translational modifications, such as phosphorylation, acetylation and ubiquitination. [20].

The involvement of RUNX genes in cancer was first discovered as chromosomal translocations associated with acute myeloid leukemia [21]. These translocations had resulted in fusion proteins lacking the C-terminal transactivation domains of RUNX1. Evidence for Runx1 function as a tumor suppressor gene was obtained from knock-in mice where a single Runx1-eto fusion allele caused a similar phenotype as observed for the Runx1 null mice $[22,23]$. Human RUNX3 has also been shown to act as a tumor suppressor in gastric carcinomas [24]. However, recent retroviral tagging studies have indicated that any of the three murine Runx genes can also operate as dominant oncogenes that can co-operate with $m y c$ and pim family genes in lymphomagenesis $[3,25]$. Human RUNX genes have also been observed to be amplified in childhood leukemias $[26,27]$.
Here we show that the Pim-1 kinase can physically interact with RUNX family transcription factors, colocalize with them within nuclei and phosphorylate them in vitro. Furthermore, the transactivation ability of Runx 1 is potentiated by Pim- 1 , suggesting a mechanism via which Pim-1 may regulate the activity of RUNX family transcription factors during hematopoiesis as well as in leukemogenesis.

\section{Results and discussion \\ Pim-I interacts with RUNX family proteins}

To search for putative Pim-1-interacting partners, we used the yeast two-hybrid system as previously described $[9,28]$. A kinase-deficient K67M mutant of Pim-1 fused to the LexA DNA-binding domain was used as a bait to screen a library of cDNA clones that had been isolated from Epstein-Barr virus-transformed human lymphocytes and fused to the VP16 activation domain. Out of the approximately $6 \times 10^{6}$ yeast transformants tested, 220 clones were recovered that were able to activate two separate reporter genes in a strictly Pim-1-dependent fashion.

Sequence analysis revealed that one of the strongly interacting cDNA clones, designated B19, encoded amino acids 264-404 of the human RUNX3 protein, including its C-terminal transactivation and inhibition domains, but lacking the most C-terminal end (see Figure 3B). To test whether this fragment interacted also with the wildtype Pim-1 protein, a mating assay was carried out using a modified two-hybrid assay [29] with baits fused to the GAL4 DNA-binding domain. Results from this assay indicated that the VP16-B19 fusion protein interacts equally well with both the wild-type and mutant GAL4-Pim-1 fusion proteins, but not with any control proteins tested, such as lamin or the Src kinase, as judged by the ability of the diploid yeast strains to grow on selective medium lacking histidine (Figure 1A and data not shown). The bait proteins did not activate the reporter genes on their own in the absence of the B19 fragment, while all strains were able to grow on non-selective medium containing histidine (Figure 1A and data not shown). The physical interaction observed in vivo in yeast cells was also biochemically confirmed in a GST pull-down assay, where bacterially produced GST-B19 fusion protein was specifically able to associate with in vitro translated ${ }^{35}$ S-labeled Pim-1 protein (data not shown).

To further examine the interaction between Pim-1 and full-length RUNX transcription factors within living cells, COS-7 cells were transiently transfected with vectors expressing Pim-1 and either MYC-tagged Runx1, Runx 3 or FLAG-tagged Runx1. Two days later, cells were collected and lysed, after which the cell lysates were subjected to immunoprecipitation with anti-MYC or FLAG antibodies followed by Western blotting with anti-Pim-1 antibody. 
A.

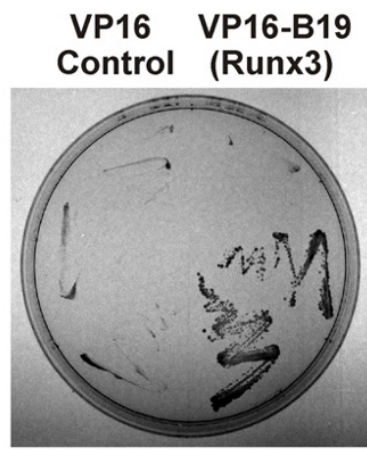

\section{GAL4-Lamin}

GAL4-Pim-1

(K67M)

GAL4-Pim-1

(WT)

B.
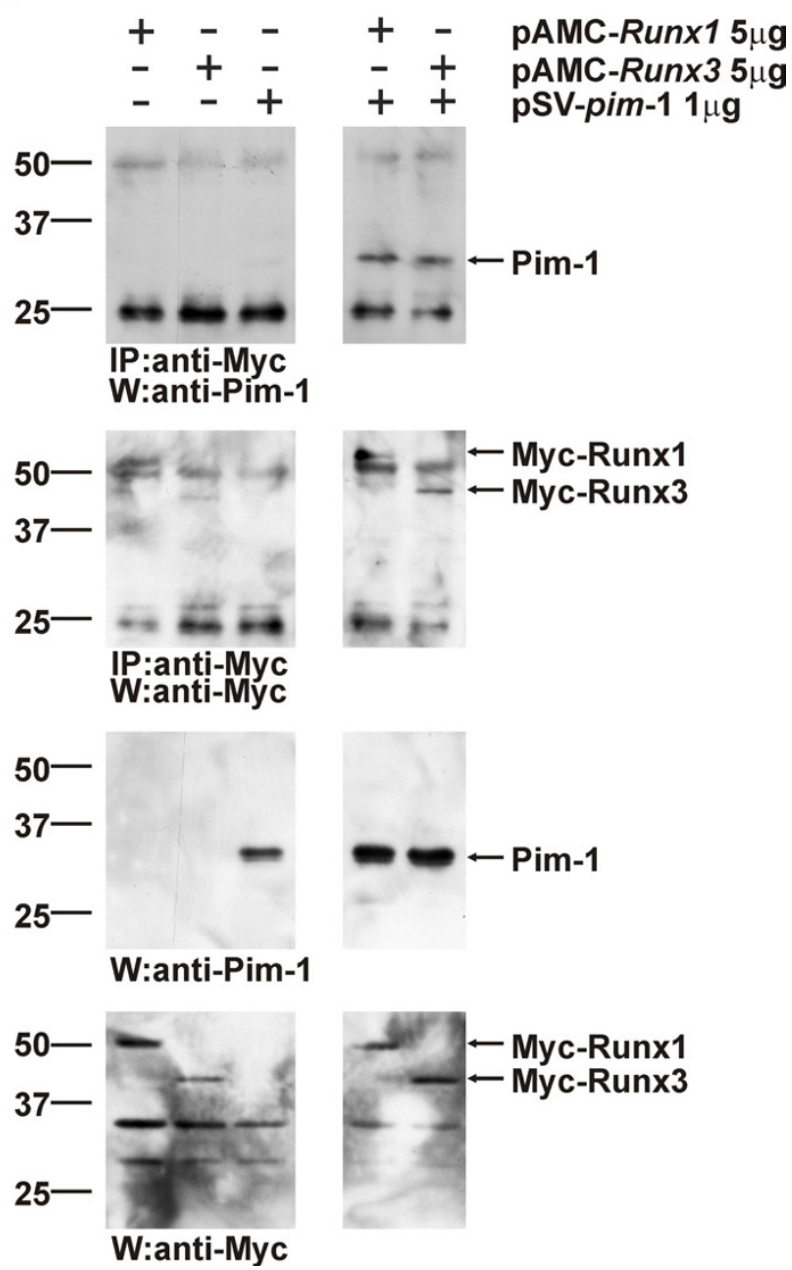

Figure I

Pim-I interacts with RUNX family proteins. (A) Yeast strains expressing the VPI6 activation domain alone or fused with the BI 9 fragment of human RUNX3 were mated with strains expressing the GAL4 DNA-binding domain fused with the control protein lamin or either kinase-deficient (K67M) or wild-type (WT) Pim-I. The ability of two proteins to interact with each other was judged based on the capacity ot the corresponding diploid strains to grow on the selective medium lacking histidine. (B) COS-7 cells were transfected with PSV-pim-I, PAMC-Runx I or PAMC-Runx3 plasmids as indicated in the figure. Parts of the cell lysates were subjected to immunoprecipitation with anti-Myc antibody followed by immunoblotting with anti-Pim-I or anti-Myc antibodies. The expression of proteins in the lysates was verified by direct Western blotting with the same antibodies. 
This analysis revealed that Pim-1 can be coprecipitated together with both Runx1 and Runx3 full-length proteins (Figure 1B and data not shown).

\section{Pim-I colocalizes with Runx I and Runx3 proteins in nucleus}

To be able to investigate the intracellular distribution and possible colocalization of Pim-1 and RUNX proteins, COS-7 cells were transiently transfected with vectors expressing Pim-1 fused to the enhanced cyan fluorescent protein (ECFP) and either Runx1 or Runx3 fused to the enhanced yellow fluorescent protein (EYFP). As expected from previous studies with untagged proteins [30-32], Pim-1 protein was found both in the nucleus and the cytoplasm of interphase cells, while Runx1 and Runx3 proteins predominantly localized to the nuclei in a granular expression pattern (Figure 2). More intriguingly, both Runx1 and Runx3 colocalized with Pim-1 in the nuclei of double-positive cells, as demonstrated by scattergram analysis of merged fluorescent images from fixed as well as from living cells (Figures 2B, 2C and data not shown). Altogether, our immunoprecipitation and imaging results indicated that Pim-1 can colocalize and physically interact with Runx family proteins within the nuclear compartment.

\section{Pim- I can phosphorylate Runx I and Runx3 proteins in vitro}

To find out whether human or murine RUNX proteins act as substrates for the Pim-1 kinase, in vitro kinase assays were carried out with bacterially expressed proteins fused to the glutathione S-transferase (GST) protein. Wild-type GST-Pim-1, but not the corresponding kinase-deficient K67M mutant was able to phosphorylate itself, the C-terminal interacting fragment of human RUNX3 as well as the full-length murine Runx3 protein, but not the GST moiety (Figure 3A and data not shown). Pim-1 phosphorylated also several C-terminal fragments of murine Runx1 (Figure 3A). Since not all the Runx1 and Runx3 fragments overlapped with each other (Figure 3B), this suggests that there are multiple target sites for Pim-1 within the RUNX proteins.

\section{Pim-I potentiates transcriptional activity of the RUNXI transcription factor}

Phosphorylation by extracellular signal-regulated kinase (ERK) has previously been shown to potentiate the transactivation ability of RUNX1 [33]. To investigate whether phosphorylation of Runx1 by Pim-1 had similar consequences, transient transactivation experiments were carried out in Jurkat $\mathrm{T}$ cells using a previously established luciferase reporter assay with which the functional domains of Runx1 had been determined [19]. There the luciferase gene is driven by the macrophage-colony stimulating factor receptor (M-CSF-R) promoter containing binding sites for RUNX, PU.1 and C/EBP transcription factors. In Jurkat T cells, the reporter is inactive in the absence of ectopic expression of any RUNX family member and their heterodimeric binding partner $\mathrm{CBF} \beta$, while Runx1 alone only slightly activates it. Also in our assays, ectopic expression of Pim-1 was unable to stimulate luciferase activity in the absence of Runx1 (data not shown). As shown in Figure 4A, increasing amounts of wild-type Pim1 were able to enhance Runx1/Cbf $\beta$-dependent transactivation of the luciferase reporter in a statistically significant and dose-dependent fashion, as also confirmed by analysis of the steady-state levels of Pim-1 protein by Western blotting. By contrast, the kinase-deficient K67M mutant of Pim-1 did not have any major effects on Runx1 activity, while the more extensive NT81 mutant lacking the N-terminal 80 amino acids of Pim-1 even slightly inhibited it (Figure 4B). We have previously shown that this mutant can act in a dominant negative fashion to downregulate the effects of the endogenously expressed wild-type Pim-1 protein e.g. on NFATc activity [8].

To examine whether the effects of Pim-1 were mediated via the activation domain of Runx1 that Pim-1 was able to phosphorylate, additional assays were carried out with a GAL4-dependent luciferase reporter coexpressed with a fusion protein where the yeast GAL4 DNA-binding domain had been fused with the activation domain of Runx1 (amino acids 262-371) containing two major transactivation elements, TE1 and TE2 [[19], see Figure $3 \mathrm{~B}]$. Indeed, wild-type Pim-1 was able to increase luciferase activity when coexpressed with the GAL4-Runx1 fusion protein, but not with the GAL4 DNA-binding domain alone (Figure 4C). Since the kinase-deficient mutants remained inactive in this assay (data not shown), our results suggest that the effects of Pim-1 are dependent on the presence of its phosphorylation target sites within the activation domain of RUNX proteins.

Ser $^{249}$ and Ser 266 of RUNX1 have been shown to be targeted by the extracellular signal-regulated kinase (ERK) [33]. More recent studies have indicated that phosphorylation by ERK affects not only activity, but also localization and stability of RUNX1 [34]. Unphosphorylated RUNX1 interacts with the transcriptional repressor mSin3A and is associated with nuclear matrix. Phosphorylation of RUNX1 by the ERK-dependent pathway releases RUNX1 from mSin3A and nuclear matrix, and this is accompanied with enhanced transcriptional activity. However, since binding to mSin3A protects RUNX1 from proteosome-mediated degradation, corepressor release from RUNX1 may regulate its transcriptional activity in a time-dependent fashion, and thereby prevent prolonged RUNX1 activation in response to cytokines or growth factors. Since none of the amino acid sequences surrounding ERK-phosphorylated or other C-terminal serine or threo- 


\section{A. ECFP-Pim-1}

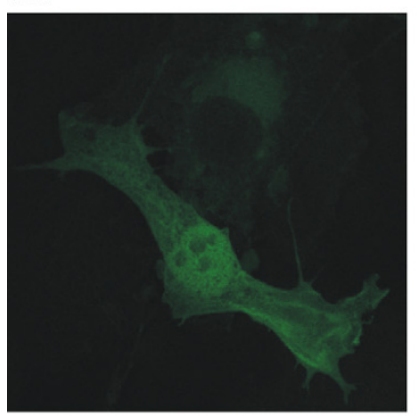

B.
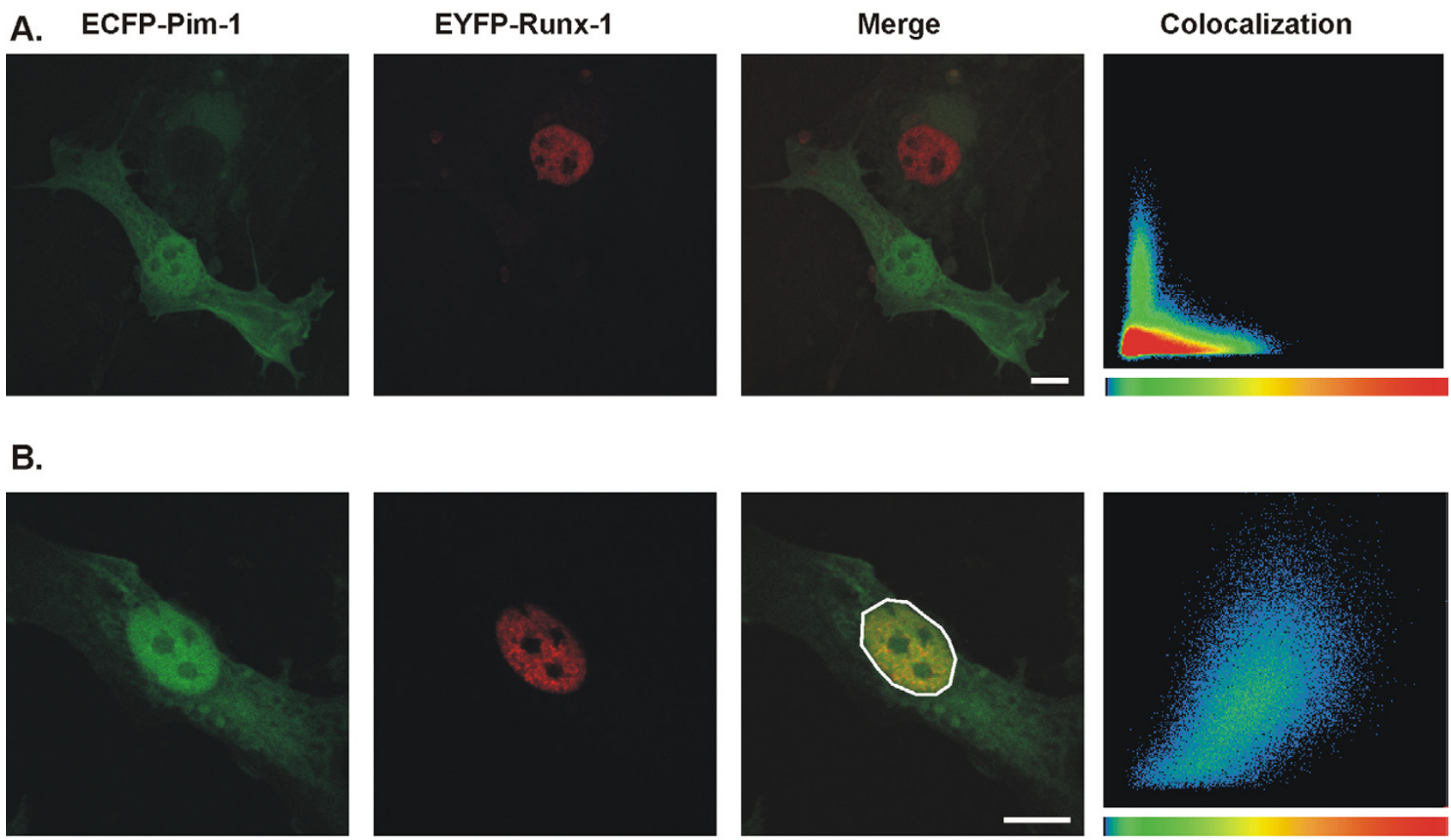

\section{ECFP-Pim-1}

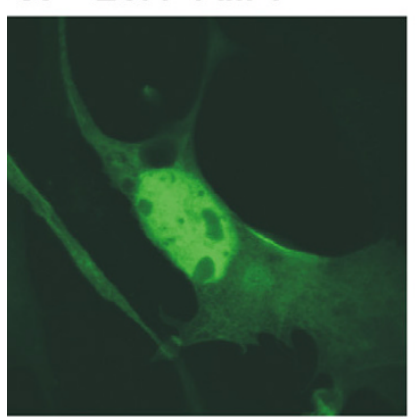

EYFP-Runx-3

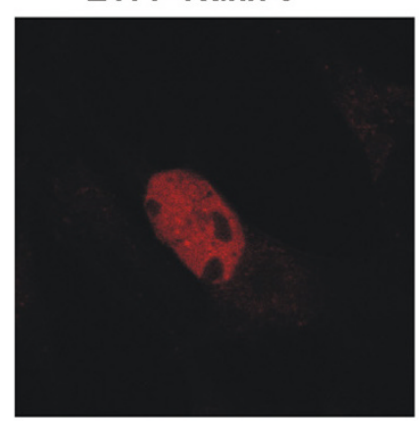

Merge

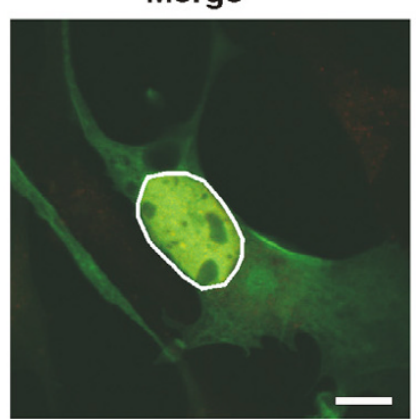

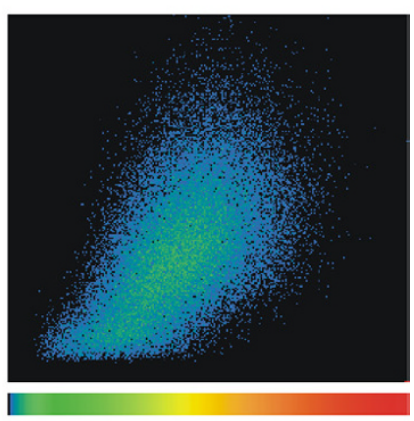

\section{Colocalization}

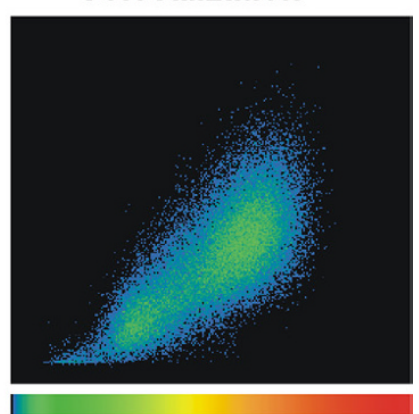

\section{Figure 2}

Pim-I colocalizes with Runx-I and Runx-3. The subcellular distribution of ECFP-Pim-I, EYFP-RunxI and EYFP-Runx3 was analysed from transiently transfected COS-7 cells under confocal microscope. Shown are single- (A) or double-positive (B, C) cells expressing indicated fluorescent proteins. Colocalization of ECFP (first panel) and EYFP (second panel) fusion proteins in the circled nuclei was visualized by yellow colour in merged images (third panel) and was confirmed by scattergram plots (fourth panel), where the intensities of the CFP and YFP channels are on the X-and Y-axis, respectively. Bar represents $20 \mu \mathrm{m}$. 


\section{Aho et al.}

Figure 3.

A.

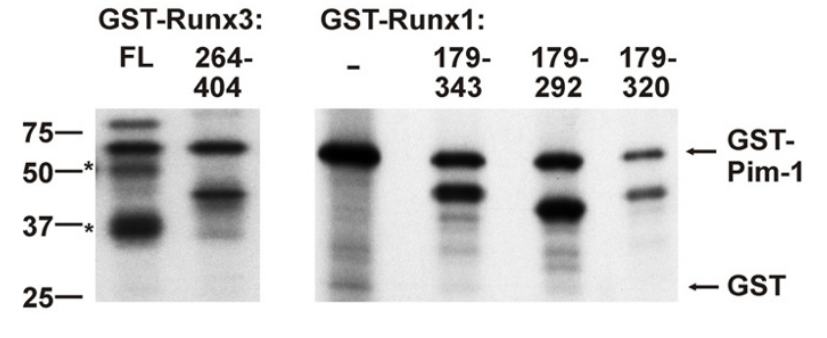

B.

\begin{tabular}{|c|c|c|c|c|c|}
\hline \multicolumn{3}{|c|}{ Runx1 } & $A D$ & \multicolumn{2}{|c|}{ VWRPY } \\
\hline 1 & 177 & 243 & $2 \overline{29133137}$ & 71411 & 451 \\
\hline & Runt domain & \begin{tabular}{l|l} 
TE3 \\
\end{tabular} & \begin{tabular}{|l|} 
TE1 TE2 \\
\end{tabular} & ID & \\
\hline
\end{tabular}

\begin{tabular}{ll} 
Runx3 & $264-404$ \\
Runx1 & $179-320 \square$ \\
Runx1 & $179-292 \square$ \\
Runx1 & $179-343 \square$ \\
\hline
\end{tabular}

Figure 3

Pim-I phosphorylates Runx proteins in vitro. (A) Bacterially produced GST fusion proteins expressing either fulllength (FL) or fragments of Runxl or Runx3 were incubated with GST-Pim-I in in vitro kinase assays. The phosphorylation products were separated on SDS-PAGE and visualized by autoradiography. GST alone (-) was used as a negative control. * indicates protein degradation products. (B) Schematic presentation of the functional domains of RunxI, including the Runt domain, an activation domain (AD) with two major transactivation elements (TEI and TE2), a minor transactivation element (TE3), an inhibitory domain (ID) and the C-terminal VWRPY sequence. Shown are also the fragments phosphorylated by Pim-I in RunxI or Runx3, which lacks the sequences corresponding to TE3 of Runxl.

nine residues in RUNX1 show obvious homology to the reported Lys/Arg-rich Pim-1 consensus phosphorylation site [35], the Pim-1 target sites as well as the putative effects of the Pim-1 kinase on stability of RUNX proteins remain to be identified.

\section{Pim-I may regulate hematopoietic cell fate together with RUNX proteins}

Enforced expression of Runx 2 and $g f i$ - 1 transcription factors in murine thymocytes has been shown to result in delayed thymocyte development at the stage of $\beta$-selection where cells rearrange their T cell receptor $\beta$ (TCR $\beta$ ) locus [36,37]. Interestingly, Pim-1 is able to promote maturation of double negative (DN) thymocytes into double positive (DP) thymocytes in Rag-deficient and TCR $\beta$ enhancer-deleted mice, which are deficient in $\beta$-selection
A.
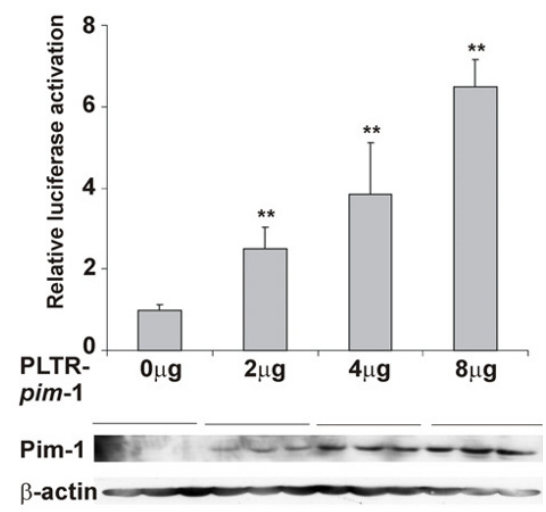

B.
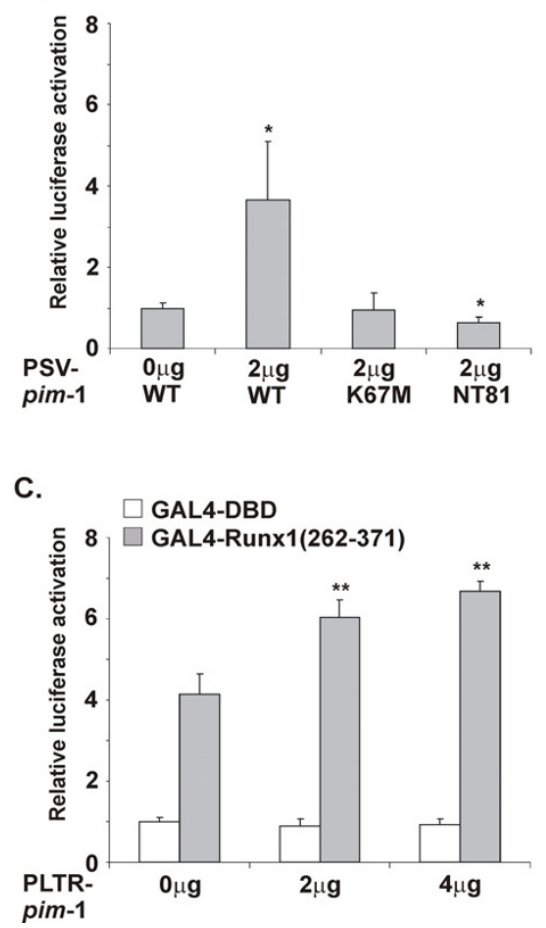

\section{Figure 4}

Pim-I potentiates transcriptional activity of RunxI. (A) Jurkat TAg-cells were transfected with $4 \mu \mathrm{g}$ of pM-CSFR-Luc, I $\mu \mathrm{g}$ of pSV- $\beta$-gal, $4 \mu \mathrm{g}$ of pEF-Runx I, $2 \mu \mathrm{g}$ of pEF$\mathrm{Cbf} \beta 2$, and indicated amounts of pLTR-pim- I. The steadystate levels of Pim-I protein were measured from the same cell lysates by Western blotting with anti-Pim-I antibody and equal loading was verified with anti- $\beta$-actin antibody. (B) Jurkat TAg-cells were transfected with same reporter constructs as in Figure $A$ together with wild-type or mutant PSVpim-I constructs. (C) Jurkat TAg-cells were transfected with $3 \mu \mathrm{g}$ of pG5-Luc, I $\mu \mathrm{g}$ of pSV- $\beta$-gal, $3 \mu \mathrm{g}$ of GAL4 fusion proteins and $2 \mu \mathrm{g}$ of $\mathrm{pEF}-\mathrm{Cbf} \beta 2$ together with indicated amounts of pLTR-pim-I. Shown are relative luciferase activities normalized against $\beta$-galactosidase activities and statistically analysed by Student's t-test $(*, p \leq 0.05 ; * *, p \leq 0.0$ I). 
as are also mice overexpressing Gfi-1 [37-39]. In addition, intact Runx1 protein is required for cell proliferation during DN-to-DP transition [40]. Thus, strict spatio-temporal expression of all these proteins is important for development of DN thymocytes into more mature DP T cells and further into functional mature single positive effector $\mathrm{T}$ cells.

Both pim and Runx family genes can cooperate with myc family genes in tumor formation $[1,25]$, which correlates well with the observation that both Runx1 and Runx3 were found among the genes that could substitute for pim-1 and pim-2 in retroviral tagging experiments [41]. However, pim-1 and Runx2 have also been shown to cooperate with each other [3], suggesting that these genes are not completely redundant in their oncogenic effects and that RUNX family transcription factors may function both in parallel as well as downstream of Pim kinase-modulated pathways.

\section{Conclusion}

Our data indicate that the Pim-1 serine/threonine kinase is able to physically interact with the RUNX family transcription factors, colocalize with them within nuclei and phosphorylate them in vitro. Moreover, the transcriptional activity of at least Runx1, but most likely also of other RUNX family members is potentiated by Pim-1. These results have revealed a previously unrecognized signaling cascade involving Pim-1 kinase and the RUNX family of transcription factors that may control differentiation and transformation of hematopoietic cells.

\section{Methods \\ Plasmids}

Eukaryotic pLTR-pim-1, pSV-pim-1, pECFP-pim-1 and prokaryotic GST-Pim-1 fusion vectors expressing the wildtype murine protein or the kinase-deficient $\mathrm{K} 67 \mathrm{M}$ or NT81 mutants have been described previously $[8,30]$ as also all yeast vectors used [9], pEF-BOS, pEF-Runx1, pEFRunx3, pEF-Cbf $\beta 2$ and GAL4-Runx1 fusion constructs and the prokaryotic GST fusion vectors expressing murine Runx proteins and their deletion derivatives [19,24]. Two additional deletion derivatives Runx1(179-292) and Runx1(179-320) were made by digesting GSTRunx1(179-343) vector with Sal I or Sph I restriction enzymes, respectively. GST-B19 was prepared from the yeast VP16-B19 fusion vector expressing amino acids 264-404 of human RUNX3. MYC-tagged Runx1 and Runx3 as well as FLAG-tagged Runx1 expression vectors were prepared by PCR from pEF-Runx1 and pEF-Runx3 plasmids and cloned into pAMC [42], kindly provided by Dr. Tomi Mäkelä, (Biomedicum Helsinki, Finland), or pFLAG-CMV-2 (Kodak) vectors, respectively. Runx proteins fused to the enhanced yellow fluorescent protein were subcloned into the pEYFP-C1 vector from Clontech.
M-CSF-R-Luc reporter plasmid was kindly provided by Dr. Dong Er-Zhang (Harvard Medical School, Boston, MA), while GAL4-luciferase (G5-Luc) and pSV- $\beta$-galactosidase (pSV- $\beta$-gal) reporter plasmids were from Promega.

\section{Cell culture}

Jurkat T cell derivatives, JTAg cells expressing the SV40 Tantigen [43] were maintained in Roswell Park Medical Institute (RPMI) medium (Sigma-Aldrich) supplemented with $10 \%$ fetal bovine serum, $100 \mu \mathrm{g} / \mathrm{ml}$ streptomycin, and 100 units/ml penicillin, while Dulbecco's modified Eagle's medium (DMEM) (Sigma-Aldrich) with equal supplements was used to grow COS-7 cells.

\section{Yeast two-hybrid assays}

Yeast two-hybrid assays were carried out essentially as previously described [9,28]. Briefly, the K67M mutant of Pim-1 fused with the LexA DNA-binding domain was used as a bait to screen a library kindly provided by Stephen Elledge (Baylor College of Medicine, Houston, Texas). The library contained cDNA clones isolated from Epstein-Barr virus-transformed human peripheral blood lymphocytes and fused to the VP16 activation domain. The yeast transformants expressing Pim-1-interacting protein fragments were double-selected for their abilities to grow on histidine-deficient plates containing $25 \mathrm{mM} 3$ aminotriazole and to produce $\beta$-galactosidase. To further verify double-positive interactions, mating assays were carried out using a modified yeast two-hybrid assay [29] with baits fused with the GAL4 DNA-binding domain. Nucleotide sequences for the positive clones were determined using an Applied Biosystems automated sequencing apparatus.

\section{Protein interaction assays}

GST pull-down assays were carried out as previously described [30] with bacterially produced GST-fusion proteins and in vitro translated ${ }^{35} \mathrm{~S}$-labeled Pim-1 protein. For coprecipitation assays, COS-7 cells were transfected by electroporation $(220 \mathrm{~V}, 975 \mu \mathrm{F})$ with Gene Pulser II (BioRad). Two days later, cells were collected and lysed by one freeze-thaw cycle into co-IP buffer $(50 \mathrm{mM}$ Tris- $\mathrm{HCl}, \mathrm{pH}$ 7.5, $150 \mathrm{mM} \mathrm{NaCl}, 0.1 \mathrm{mM}$ EDTA, $0.5 \%$ NP-40, 20\% glycerol and 1:100 Protease Inhibitor mix (SigmaAldrich)). $100 \mu \mathrm{g}$ aliquots of protein were used to confirm protein expression by Western blotting, whereas $500 \mu \mathrm{g}$ aliquots of protein were subjected to immunoprecipitation with mouse monoclonal anti-MYC (Sigma-Aldrich) or M2 anti-FLAG (Kodak) antibodies bound to protein Gsepharose beads (Amersham Biosciences) for 2 hours or overnight at $4^{\circ} \mathrm{C}$. Precipitated proteins were washed 5-6 times with co-IP buffer, resolved on SDS-PAGE and transfered onto PVDF membrane (Amersham Pharmacia Biotech). To detect proteins by Western blotting, membranes were incubated with mouse monoclonal anti-Pim-1 
(19F7; Santa Cruz Biotechnology), anti-MYC (SigmaAldrich), M2 anti-FLAG (Kodak) or anti- $\beta$-actin (SigmaAldrich) antibodies followed by HRP-linked anti-mouse antibodies (Zymed), and the ECL+plus chemiluminescence reagents (Amersham Biosciences).

\section{Cell imaging assays}

COS-7 cells were transiently transfected with ECFP or EYFP fusion vectors as described above and plated on coverslips. Two days later, cells were fixed with $4 \%$ paraformaldehyde, after which confocal images were captured with Zeiss LSM510 META confocal microscope. ECFP and EYFP fusion proteins were excited with $405 \mathrm{~nm}$ and 514 nm laser lines and emissions were collected with BP 435485 and LP 560 filters, respectively. The optical thicknesses of the two channels were equalized prior to image acquisition and colocalization was visualized with a scattergram plot acquired with Zeiss LSM510 3.2 program.

\section{In vitro kinase assays}

In vitro kinase assays were carried out as previously described [8]. Briefly, bacterially produced GST-fusion proteins were mixed in kinase buffer (20 mM Pipes, $\mathrm{pH}$ 7.0, $5 \mathrm{mM} \mathrm{MnCl}_{2}, 7 \mathrm{mM} \beta$-mercaptoethanol, $0.25 \mathrm{mM} \beta$ glycerophosphate, $0.4 \mathrm{mM}$ spermine, $10 \mu \mathrm{M}$ rATP, 1:200 aprotinin (Sigma-Aldrich) supplemented with $10 \mu \mathrm{Ci}$ of $\gamma$-32P-ATP (Amersham Biosciences) and incubated at $30^{\circ} \mathrm{C}$ for 30 minutes. Samples were separated on SDSPAGE and visualized by autoradiography.

\section{Transactivation assays}

$5 \times$ or $10 \times 10^{6}$ Jurkat TAg-cells were transfected by electroporation $(250 \mathrm{~V}, 975 \mu \mathrm{F})$. Two days later, cells were collected and analysed for luciferase activity using Luminoskan Luminometer (Labsystems). The transfection efficiencies were normalized against $\beta$-galactosidase activities. Shown in the figures are means and standard deviations of representative examples of at least 3 independent experiments with triplicate or quadruple samples.

\section{Abbreviations}

$\beta$-gal, $\beta$-galactosidase; $\mathrm{DP}$, double positive; $\mathrm{DN}$, double negative; ECFP, enhanced cyan fluorescent protein; EYFP, enhanced yellow fluorescent protein; ERK, extracellular signal-regulated kinase; GST, Glutathione S-transferase; HRP, horse-radish peroxidase; Luc, luciferase; M-CSF-R, macrophage-colony stimulating factor receptor; PVDF, polyvinylidene fluoride; TCR, T cell receptor

\section{Authors' contributions}

TLTA carried out protein interaction assays, transactivation assays and most of in vitro kinase assays, and drafted the manuscript. JS performed imaging assays and KJP yeast mating assays. YI provided reagents and expertise on
Runx proteins and critically revised the manuscript. PJK initiated the project by carrying out the yeast two-hybrid screen and some in vitro kinase assays, and supervised the work as well as writing of the manuscript. All authors read and approved the final manuscript.

\section{Acknowledgements}

This work was initiated in the laboratory of Robert Eisenman (Fred Hutchinson Cancer Research Center, Seattle, WA). We thank Stephen Elledge, Dong-Er Zhang and Tomi Mäkelä for reagents, and Kaija-Liisa Laine and the Cell Imaging Core of the Turku Centre for Biotechnology for expert technical assistance. This work was supported by grants from the Academy of Finland (to PJK), Finnish Cultural Foundation (to TLTA and JS), Emil Aaltonen Foundation and Cancer Society of Southwestern Finland (to TLTA).

\section{References}

I. Allen JD, Berns A: Complementation tagging of cooperating oncogenes in knockout mice. Semin Cancer Biol 1996, 7:299-306. Review

2. Acton D, Domen J, Jacobs H, Vlaar M, Korsmeyer S, Berns A: Collaboration of pim $-I$ and $\mathbf{b c l}-2$ in lymphomagenesis. Curr Top Microbiol Immunol 1992, 182:293-298.

3. Blyth K, Terry A, Mackay N, Vaillant F, Bell M, Cameron ER, Neil JC, Stewart M: Runx2: a novel oncogenic effector revealed by in vivo complementation and retroviral tagging. Oncogene $200 \mathrm{I}$, 20:295-302.

4. Saris CJM, Domen J, Berns A: The pim-I oncogene encodes two related protein-serine/threonine kinases by alternative initiation at AUG and CUG. EMBO J 1991, I 0:655-664.

5. Dautry F, Weil D, Yu J, Dautry-Varsat A: Regulation of pim and myb mRNA accumulation by interleukin 2 and interleukin 3 in murine hematopoietic cell lines. I Biol Chem 1988, 263:176|5-17620.

6. Lilly M, Le T, Holland P, Hendrickson SL: Sustained expression of the pim-I kinase is specifically induced in myeloid cells by cytokines whose receptors are structurally related. Oncogene 1992, 7:727-732.

7. Matikainen S, Saraneva T, Rönni T, Lehtonen A, Koskinen PJ, Julkunen I: Interferon- $\alpha$ activates multiple STAT proteins and up-regulates proliferation-associated IL-2R $\alpha$, c-myc, and pim-I genes in human T cells. Blood 1999, 93:1980-1991.

8. Rainio EM, Sandolm J, Koskinen PJ: Cutting edge: Transcriptional activity of NFATcl is enhanced by Pim-I kinase. I Immunol 2002, I68:I524-I527.

9. Leverson JD, Koskinen PJ, Orrico FC, Rainio EM, Jalkanen KJ, Dash $A B$, Eisenman RN, Ness SA: Pim-I kinase and p 100 cooperate to enhance c-Myb activity. Mol Cell I998, 2:4I7-425.

10. Rainio EM, Ahlfors H, Carter KL, Ruuska M, Matikainen S, Kieff E, Koskinen PJ: Pim kinases are upregulated during Epstein-Barr virus infection and enhance EBNA2 activity. Virology 2005, 333:201-206.

II. Chen XP, Losman JA, Cowan S, Donahue E, Fay S, Vuong BQ, Nawijn MC, Capece D, Cohan VL, Rothman P: Pim serine/threonine kinases regulate the stability of Socs-I protein. Proc Natl Acad Sci USA 2002, 99:2175-2180.

12. Peltola KJ, Paukku K, Aho TLT, Ruuska M, Silvennoinen O, Koskinen PJ: Pim-I kinase inhibits STAT5-dependent transcription via its interactions with SOCSI and SOCS3. Blood 2004, I 03:3744-3750.

I3. Bachmann M, Möröy T: The serine/threonine kinase Pim-I. Int J Biochem Cell Biol 2005, 37:726-730. Review

14. Van Wijnen AJ, Stein GS, Gergen JP, Groner Y, Hiebert SW, Ito Y, Liu $P$, Neil JC, Ohki M, Speck N: Nomenclature for Runt-related (RUNX) proteins. Oncogene 2004, 23:4209-4210.

15. Coffman IA: Runx transcription factors and the developmental balance between cell proliferation and differentiation. Cell Biol Int 2003, 27:3 I5-224. Review

16. de Bruijn MFTR, Speck NA: Core-binding factors in hematopoiesis and immune function. Oncogene 2004, 23:4238-4248. Review

17. Gergen JP, Butler BA: Isolation of the Drosophila segementation gene runt and analysis of its expression during embryogenesis. Genes Dev 1988, 2:II79-II93. 
18. Ito $Y$ : Molecular basis of tissue-specific gene expression mediated by the runt domain transcription factor PEBP2/CBF. Genes Cells 1999, 4:685-696. Review

19. Kanno T, Kanno Y, Chen L-F, Ogawa E, Kim W-Y, Ito Y: Intrinsic transcriptional activation-inhibition domains of the polyomavirus enhancer binding protein $2 /$ core binding factor alpha subunit revealed in the presence of the beta subunit. Mol Cell Biol 1998, 1 8:2444-2454.

20. Bae S-C, Lee YH: Phosphorylation, acetylation and ubiquitination: The molecular basis of RUNX regulation. Gene 2005 in press. Review

21. Miyoshi H, Shimizu K, Kozu T, Maseki N, Kaneko Y, Ohki M: t(8;2 I) breakpoints on chromosome $2 \mathrm{I}$ in acute myeloid leukemia are clustered within a limited region of a single gene, AMLI. Proc Natl Acad Sci USA 199I, 88: I043 I- 10434.

22. Yergeau DA, Hetherington $C J$, Wang $Q$, Zhang $P$, Sharpe $A H$, Binder M, Marin-Padilla M, Tenen DG, Speck NA, Zhang DE: Embryonic lethality and impairment of haematopoiesis in mice heterozygous for an AMLI-ETO fusion gene. Nat Genet 1997, 15:303-306.

23. Okuda T, Cai Z, Yang S, Lenny N, Lyu CJ, van Deursen JM, Harada H, Downing JR: Expression of a knocked-in AMLI-ETO leukemia gene inhibits the establishment of normal definitive hematopoiesis and directly generates dysplastic hematopoietic progenitors. Blood 1998, 91:3134-3143.

24. Li QL, Ito K, Sakakura C, Fukamachi H, Inoue K, Chi XZ, Lee KY, Nomura S, Lee CW, Han SB, Kim HM, Kim WJ, Yamamoto H, Yamashita N, Yano T, Ikeda T, Itohara S, Inazawa J, Abe T, Hagiwara A, Yamagishi $\mathrm{H}$, Ooe A, Kaneda A, Sugimura T, Ushijima T, Bae SC, Ito Y: Causal relationship between the loss of RUNX3 expression and gastric cancer. Cell 2002, 109:1 I3-124.

25. Cameron ER, Blyth K, Hanlon L, Kilbey A, Mackay N, Stewart M, Terry A, Vaillant F, Wotton S, Neil JC: The Runx genes as dominant oncogenes. Blood Cells Mol Dis 2003, 30:194-200. Review

26. Busson-Le Coniat M, Nguyen Khac F, Daniel MT, Bernard OA, Berger R: Chromosome 2I abnormalities with AMLI amplification in acute lymphoblastic leukemia. Genes Chromosomes Cancer 200I, 32:244-249.

27. Penther D, Preudhomme C, Talmant P, Roumier C, Godon A, Mechinaud F, Milpied N, Bataille R, Avet-Loiseau H: Amplification of AMLI gene is present in childhood acute lymphoblastic leukemia but not in adult, and is not associated with AMLI gene mutation. Leukemia 2002, 16:1 I3I-II34.

28. Hollenberg SM, Sternglanz R, Cheng PF, Weintraub H: Identification of a new family of tissue-specific basic helix-loop-helix proteins with a two-hybrid system. Mol Cell Biol 1995, 1 5:38|3-3822.

29. Durfee T, Becherer K, Chen PL, Yeh SH, Yang Y, Kilburn AE, Lee $\mathrm{WH}$, Elledge SJ: The retinoblastoma protein associates with the protein phosphatase type I catalytic subunit. Genes Dev 1993, 7:555-569.

30. Aho TL, Sandholm J, Peltola KJ, Mankonen HP, Lilly M, Koskinen PJ: Pim-I kinase promotes inactivation of the pro-apoptotic Bad protein by phosphorylating it on the Ser I 12 gatekeeper site. FEBS Lett 2004, 571:43-49.

31. Lu J, Maruyama M, Satake M, Bae SC, Ogawa E, Kagoshima H, Shigesada $K$, Ito $Y$ : Subcellular localization of the alpha and beta subunits of the acute myeloid leukemia-linked transcription factor PEBP2/CBF. Mol Cell Biol 1995, 15:|65|-|66|.

32. Le XF, Groner Y, Kornblau SM, Gu Y, Hittelman WN, Levanon D, Mehta K, Arlinghaus RB, Chang KS: Regulation of AML2/CBFA3 in hematopoietic cells through the retinoic acid receptor $\alpha-$ dependent signaling pathway. I Biol Chem 1999, 274:2165I-21658.

33. Tanaka T, Kurokawa M, Ueki K, Tanaka K, Imai Y, Mitani K, Okazak K, Sagata N, Yazaki Y, Shibata Y, Kadowaki T, Hirai H: The extracellular signal-regulated kinase pathway phosphorylates AMLI, an acute myeloid leukemia gene product, and potentially regulates its transactivation function. Mol Cell Biol 1996, 16:3967-3979.

34. Imai Y, Kurokawa M, Yamaguchi Y, Izutsu K, Nitta E, Mitani K, Satake $M$, Noda $T$, Ito $Y$, Hirai $H$ : The corepressor $m$ Sin $3 A$ regulates phosphorylation-induced activation, intranucleosomal location, and stability of AMLI. Mol Cel Biol 2004, 24: $1033-1043$.

35. Palaty CK, Kalmar G, Tai G, Oh S, Amankawa L, Affolter M, Aebersold R, Pelech SL: Identification of the autophosphorylation sites of the Xenopus laevis Pim-I proto-oncogene-encoded protein kinase. J Biol Chem 1997, 272: I05I4-1052I.

36. Vaillant F, Blyth K, Andrew L, Neil JC, Cameron ER: Enforced expression of Runx2 perturbs $T$ cell development at a stage coincident with $\beta$-selection. J Immunol 2002, 169:2866-2874.

37. Schmidt T, Karsynky H, Rödel B, Zevnik B, Elsässer H-P, Möröy T: Evidence implicating Gfi-I and Pim-I in pre-T-cell differentiation steps associated with $\beta$-selection. EMBO J 1998, I 7:5349-5369.

38. Jacobs $H$, Krimpenfort $P$, Haks $M$, Allen J, Blom $B$, Démollière $C$ Kruisbeek $A$, Spits $H$, Berns A: PIMI reconstitues thymic cellularity in Interleukin 7- and Common $\gamma$ chain-mutant mice and permits thymocyte maturation in Rag- but not in CD3 $\gamma$ deficient mice. J Exp Med 1999, 190:1059-1068.

39. Leduc I, Karsynky H, Mathieu N, Schmidt T, Verthuy C, Ferrier P, Möröy T: The Pim-I kinase stimulates maturation of TCR $\beta$ deficient $T$ cell progrenitors: implications for the mechanism of Pim-I action. Int Immunol 2000, I 2: I 389-I396.

40. Sato T, Ito R, Nunomura S, Ohno S, Hayashi K, Satake M, Habu S: Requirement of transcription factor AMLI in proliferation of developing thymocytes. Immunol Lett 2003, 89:39-46.

4I. Mikkers H, Allen J, Knipscheer P, Romeyn L, Hart A, Vink E, Berns A: High-throughput retroviral tagging to identify components of specific sigaling pathways in cancer. Nat Genet 2002, 32:153-159.

42. Ylikorkala A, Avizienyte E, Tomlinson IP, Tiainen M, Roth S, Loukola A, Hemminki A, Johansson M, Sistonen P, Markie D, Neale K, Phillips R, Zauber P, Twama T, Sampson J, Järvinen H, Mäkelä TP, Aaltonen LA: Mutations and impaired function of LKBI in familial and non-familial Peutz-Jeghers syndrome and a sporadic testicular cancer. Hum Mol Genet 1999, 8:45-5I.

43. Northrop JP, Ullman KS, Crabtree GR: Characterization of the nuclear and cytoplasmic components of the lymphoid-specific nuclear factor of activated T cells (NF-AT) complex. Biol Chem 1993, 268:2917-2923.
Publish with BioMed Central and every scientist can read your work free of charge

"BioMed Central will be the most significant development for disseminating the results of biomedical research in our lifetime. "

Sir Paul Nurse, Cancer Research UK

Your research papers will be:

- available free of charge to the entire biomedical community

- peer reviewed and published immediately upon acceptance

- cited in PubMed and archived on PubMed Central

- yours - you keep the copyright
BioMedcentral 